\title{
Penerapan Strategi Pelaksanaan (SP) 1-4 Dengan Masalah Halusinasi Pada Penderita Skizofrenia: Studi Kasus
}

\author{
'Doni Syahdi ${ }^{1}$, Jek Amidos Pardede ${ }^{2}$ \\ Program Studi Ners Universitas Sari Mutiara Indonesia \\ *donisyahdi99@gmail.com
}

\section{BAB I}

PENDAHULUAN

\subsection{Latar Belakang}

Gangguan jiwa merupakan salah satu dari empat masalah kesehatan utama di negara-negara maju, modern dan industri, yaitu penyakit degeneratif, kanker, gangguan jiwa dan kecelakaan (Halawa, 2017). gangguan jiwa tersebut ketidak mampuan serta invaliditas tidak baik secara individu maupun kelompok akan menghambat pertumbuhan pada individu dan lingkungan, karena mereka tidak produktif dan tidak efisien. Salah satu jenis gangguan jiwa psikososial fungsional yang terbanyak adalah Skizofrenia dengan tanda dan gejala halusinasi merupakan suatu gangguan psikotik yang dapat di tandai dengan gangguan utama pikiran, persepsi, emosi dan perilaku (Davidson, Neale \& Kring 2015). Privalensi ganguan jiwa di Indonesia di urutan pertama Provinsi Bali 11,1\% dan nomor dua disusul oleh Provinsi DI Yogyakarta 10,4\%, NTB 9,6\%, Provinsi Sumatera Barat 9,1\%, Provinsi Sulawesi Selatan 8,8\%, Provinsi Aceh 8,7\%, Provinsi Jawa Tengah 8,7\%, Provinsi Sulawesi Tengah 8,2\%, Provinsi Sumatera Selatan 8\%, Provinsi Kalimantan Barat 7,9\%. Sedangkan Provinsi Sumatera Utara berada pada posisi ke 21 dengan privalensi 6,3\% (Kemenkes, 2019).

Menurut WHO (2019) Skizofrenia merupakan suatu gangguan jiwa berat yang bersifat berat dan kronis yang menyerang 20 juta orang di seluruh dunia. 
Skizofrenia merupakan penyakit kronis, parah, dan melumpuhkan, gangguan otak yang di tandai dengan pikiran kacau, waham, delusi, halusinasi, dan perilaku aneh atau katatonik (Pardede \& Laia, 2020). Negara berkembang seperti Indonesia penderita gangguan jiwa dari data yang diambil (Riskesdas, 2018) penderita skizofrenia mengalami peningkatan sebesar 5,3\% terutama untuk skizofrenia berat seperti gangguan perilaku hingga dengan

pasung. Kasus tertinggi terdapat di Bali (11\%), Di wilayah Jawa Timur data yang tercatat 2018 penderita skizofrenia sebesar 7,5\% (Riskesdas, 2018)

Skizofrenia merupakan salah satu bentuk gangguan jiwa kronik, yang menyebabkan penyakit otak persisten serius yang mengakibatkan perilaku psikotik, pemikiran konkret, dan kesulitan dalam memperoleh informasi. (Pardede. \& Hasibuan, 2020). Skizofrenia menimbulkan distorsi pikiran, distorsi persepsi, emosi, dan tingkah laku sehingga klien dengan skizofrenia memiliki resiko lebih tinggi berperilaku agresif dimana perubahan perilaku secara dramatis terjadi dalam beberapa hari atau minggu (Baradero, 2016). Klien skizoprenia sering dikaitkan dengan perilaku kekerasan yang dapat membahayakan diri sendiri maupun orang lain ataupun berisiko juga dengan lingkungan sekitarnya, baik secara fisik, emosional, seksual, dan verbal (Sutejo,2018).

Halusinasi merupakan keadaan seseorang mengalami perubahan dalam pola dan jumlah stimulasi yang di prakarsai secara internal atau eksternal disekitar dengan pengurangan berlebihan,distorsi,atau kelainan berespon terhadap setiap stimulasi (Pardede,Silitonga \& Laia,2020). Menurut Stuart (2016) klien halusinasi menjadi menarik diri tidak mau menceritakan hal yang mereka alami karena mereka takut lebih mendapatkan pandangan negative dari orang lain terkait pikiran mereka yang tidak wajar.

Survei awal di lakukan di di ruangan Sibual Buali dengan jumlah pasien 25 orang yang mengalami skizofrenia dan 16 orang mengalami halusinasi tetapi yang 
menjadi subjek di dalam asuhan keperawatan ini adalah Tn.L, penyebab Tn.L sebagai subjek di karenakan klien belum biasa mengatasi halusinasinya selain minum obat. Maka tujuan asuhan keperawatan yang akan di lakukan ialah untuk mengajarkan Strategi pelaksanaan masalah halusinasi pendengaran pada saat Tn.L mengalami halusinasi tersebut. Sehingga penulis tertarik mengangkat kasus Tn. L.

\subsection{Rumusan Masalah}

Berdasarkan masalah yang telah dipaparkan pada latar belakang maka rumusan masalah dalam askep ini yaitu : Asuhan Keperawatan Jiwa pada Tn.L. Dengan : Halusinasi Pendengaran di Rsj.Prof Muhammad Ildrem Medan

\subsection{Tujuan.}

\subsubsection{Tujuan Umum}

Mahasiswa mampu menerapkan asuhan keperawatan jiwa pada Tn.L dengan Halusinasi Pendengaran di Rsj. Dr. Prof Muhammad Ildrem Medan

\subsubsection{Tujuan Khusus}

1. Mahasiswa mampu melakukan pengkajian pada Tn.L dengan gangguan persepesi sensori : halusinasi pendengaran.

2. Mahasiswa mampu menegakkan diagnose keperawatan yang ada pada Tn.L dengan gangguan persepsi sensori : halusinasi pendengaran.

3. Mahasiswa mampu menetapkan perencanaan keperawatan pada Tn.L dengan gangguan persepsi sensori : halusinasi pendengaran.

4. Mahasiswa mampu melakaukan implementasi keperawatan pada Tn.L dengan gangguan persepsi sensori : halusinasi pendengaran.

5. Mahasiswa mampu mengevaluasi hasil asuhan keperawatan pada Tn.L dengan gangguan persepsi sensori : halusinasi pendengaran. 
6. Mahasiswa mampu melakukan pendokumentasikan asuhan keperawatan yang diberikan pada Tn.L dengan gangguan persepsi sensori : halusinasi pendengaran. 


\section{BAB 2}

\section{TINJAUAN TEORI}

\subsection{Konsep Halusinasi}

\subsubsection{Defenisi}

Halusinasi adalah gangguan persepsi sensori dari suatu obyek rangsangan dari luar, gangguan persepsi sensori ini meliputi seluruh pancaindra. Halusinasi merupakan salah satu gejala gangguan jiwa yang klien mengalami perubahan sensori persepsi, serta merasakan sensasi palsu berupa suara, penglihatan, pengecapan, perabaan, atau penciuman. Klien merasakan stimulus yang sebetulnya tidak ada. Klien gangguan jiwa mengalami perubahan dalam hal orientasi realitas (Yusuf, et al, 2015).

Halusinasi adalah distorsi persepsi palsu yang terjadi pada respons neurobiologis maladaptive. klien merasakan stimulasi yang sebetulnya tidak ada. halusinasi penglihatan dan pendengaran yang merupakan gejala dari early psychosis, yang sebagian besar terjadi pada usia remeja akhir atau dewasa awal,bingung peran yang berdampak pada rapuhnya kepribadian sehingga terjadi gangguan konsop diri dan menarik diri dari lingkungan social yang lambat laun membuat penderita menjadi asik dengan hayalan dan menyebabkan timbulnya halusinasi. (Ervina,2018). Dampak yang muncul akibat gangguan halusinasi adalah hilangannya kontrol diri yang menyebabkan seseorang menjadi panik dan perilakunya dikendalikan oleh halusinasi. Dalam situasi ini penderita halusinasi dapat melakukan tindakan merusak lingkungan,mencelaki orang lain,bahkan melakukan bunuh diri agar tidak berdampak buruk maka penderita halusinasi harus segera ditangani secara tepat.(Scott,2017)

Dari defenisi di atas dapat disimpulkan Halusinasi adalah gangguan persepsi sensori dari suatu obyek rangsangan dari luar, gangguan persepsi sensori ini meliputi seluruh pancaindra. Halusinasi biasanya muncul pada klien gangguan 
jiwa diakibatkan terjadinya perubahan orientasi realita,klien meraskan stimulasi yang sebetulnya tidak ada. Dampak yang muncul akibat gangguan halusinasi adalah hilangannya kontrol diri yang menyebabkan seseorang menjadi panik dan perilakunya dikendalikan oleh halusinasi.

\subsubsection{Klasifikasi Halusinasi}

Menurut Yusuf (2015) klasifikasi halusinasi dibagi menjadi 5 yaitu:

\begin{tabular}{|c|c|c|c|}
\hline No & $\begin{array}{l}\text { Jenis } \\
\text { halusinasi }\end{array}$ & Data Objektif & Data Subjektif \\
\hline 1. & $\begin{array}{l}\text { Halusinasi } \\
\text { pendengaran }\end{array}$ & $\begin{array}{l}\text { 1. Bicara atau tertawa } \\
\text { sendiri tanpa lawan } \\
\text { bicara } \\
\text { 2. Marah-marah tanpa } \\
\text { sebab mencondongkan } \\
\text { telinga kea rah tertentu } \\
\text { 3. Menutup Telinga }\end{array}$ & $\begin{array}{l}\text { 1. Mendengar suara atau } \\
\text { kegaduhan } \\
\text { 2. Mendengar suara yang } \\
\text { mengajak bercakap-cakap } \\
\text { 3. Mendengar suara yang } \\
\text { menyuruh melakukan } \\
\text { sesuatu yang berbahaya }\end{array}$ \\
\hline 2. & $\begin{array}{l}\text { Halusinasi } \\
\text { Penglihatan }\end{array}$ & $\begin{array}{l}\text { 1. Menunjuk-nunjuk ke } \\
\text { arah tertentu } \\
\text { 2. Ketakutan pada objek } \\
\text { yang tindak jelas }\end{array}$ & $\begin{array}{l}\text { 1. Melihat } \\
\text { bayangan,sinar,bentuk } \\
\text { geometris,bentuk } \\
\text { kartun,melihat hantu } \\
\text { atau monster }\end{array}$ \\
\hline 3. & $\begin{array}{l}\text { Halusinasi } \\
\text { Penghidu }\end{array}$ & $\begin{array}{l}\text { 1. Menghidu seperti sedang } \\
\text { membaui bau-bauan } \\
\text { tertentu } \\
\text { 2. Menutup hidung }\end{array}$ & $\begin{array}{l}\text { 1. Membaui bau-bauan } \\
\text { seperti } \\
\text { darah,urine,feses, bau } \\
\text { 2. Kadang-kadang bau itu } \\
\text { menyengkan }\end{array}$ \\
\hline 4. & $\begin{array}{l}\text { Halusinasi } \\
\text { pengecapan }\end{array}$ & $\begin{array}{l}\text { 1. Sering meludah } \\
\text { 2. Muntah }\end{array}$ & $\begin{array}{l}\text { 1. Merasakan rasa seperti } \\
\text { darah,uirine,feses }\end{array}$ \\
\hline 5. & $\begin{array}{l}\text { Halusinasi } \\
\text { Perabaan }\end{array}$ & $\begin{array}{l}\text { Menggaruk-garuk } \\
\text { permukaan kulit }\end{array}$ & $\begin{array}{l}\text { 1. Mengatakan ada serangga } \\
\text { di permukaan kulit } \\
\text { 2. Merasa seperti tersengat } \\
\text { listrik }\end{array}$ \\
\hline
\end{tabular}




\subsubsection{Etiologi}

Faktor predisposisi klien halusinasi menurut ( Oktiviani,2020 ) :

1. Faktor Predisposisi

- Faktor perkembangan

Tugas perkembangan klien terganggu misalnya rendahnya kontrol dan kehangatan keluarga menyebabkan klien tidak mampu mandiri sejak kecil,mudah frustasi,hilang percaya diri.

- Faktor sosiokultural

Seseorang yang merasa tidak diterima dilingkungan sejak bayi akan merasa disingkirkan,kesepian,dan tidak percaya pada lingkungan.

- Biologi

Faktor biologis mempunyai pengaruh terhadap terjadinya gangguan jiwa.adanya stress yang berlebihan dialami seseorang maka didalam tubuh akan dihasilkan suatu zat yang dapat bersifat halusinogen neurokimia.Akibat stress berkepanjangan menyebabkan teraktivitasnya neurotransmitter otak.

- Psikologis

Tipe kepribadian lemah dan tidak bertanngung jawab mudah terjerumus pada penyalahgunaan zat adiktif.Hal ini berpengaruh pada ketidakmampuan psien dalam mengambil keputusan yang tepat demi masa depannya,klien lebih memilih kesenangan sesaat dan lari dari alam nyata menuju alam khayal.

- Sosial Budaya

Meliputi klien mengalami interaksi social dalam fase awal dan comfortin, klien menganggap bahwa hidup bersosialisasi di alam nyata sangat membahayakan. Klien asyik dengan Halusinasinya, seolah-olah ia merupakan tempat untuk memenuhi kebutuhan akan interaksi social, kontrol diri dan harga diri yang tidak didapatkan dalam dunia nyata. 


\section{Faktor Presipitasi}

Menurut Stuart dan Sudeen faktor presipita dapat meliputi (Prabowo,2015) :

- Biologis

Gangguan dalam komunikasi dan putaran balik otak,yang mengatur proses informasi serta abnormalitas pada mekanisme pintu masuk dalam otak yang mengakibatkan ketidakmampuan untuk secara selektif menanggapi stimulus yang diterima oleh otak untuk diinterpretasikan.

- Stress lingkungan

Ambang toleransi terhadap stress yang berinteraksi terhadap stressor lingkungan untuk menentukan terjadinya gangguan perilaku.

- Sumber koping

Sumber koping mempengaruhi respon individu dalam menanggapi stressor.

\subsubsection{Rentang Respon Neurobiologi}

Rentang repon tersebut dapat digambarkan seperti dibawah ini (Muhith,2015)

\section{Adaptif}

Mal adaptif

\begin{tabular}{|c|c|c|}
\hline $\begin{array}{l}\text { 1. Pikiran } \\
\text { 2. Persepsi akurat } \\
\text { 3. Erosi konsisten } \\
\text { dengan pengalaman } \\
\text { 4. Perilaku sesuai } \\
\text { 5. Berhubungan sosial } \\
\quad \mathrm{r}\end{array}$ & $\begin{array}{l}\text { 1. Distorsi pikiran } \\
\text { ilusi } \\
\text { 2. Reaksi emosi } \\
\text { berlebihan } \\
\text { 3. Perilaku aneh atau } \\
\text { tidak biasa } \\
\text { 4. Menarik diri }\end{array}$ & $\begin{array}{l}\text { 1. Gangguan } \\
\text { piker/delusi } \\
\text { 2. Halusinasi } \\
\text { 3. Sulit merespon } \\
\text { emosi } \\
\text { 4. Perilaku } \\
\text { disorganisasi } \\
\text { 5. Isolasi social }\end{array}$ \\
\hline
\end{tabular}

a. Respon adaptif adalah respon yang dapat diterima oleh norma-norma social budaya yang berlaku.Dengan kata lain individu tersebut dalam batas normal jika menghadapi suatu akan dapat memecahkan masalah tersebut . 
1. Respon adaptif meliputi :

1) Pikiran logis adalah pandangan yang mengarah pada kenyataan

2) Persepsi akurat adalah pandangan yang tepat pada kenyataan

3) Emosi konsisten dengan pengalaman yaitu perasaan yang timbul dari pengalaman ahli.

4) Perilaku sesuai adalah sikap dan tingkah laku yang masih dalam batas kewajaran.

5) Hubungan social adalah proses suatu interkasi dengan orang lain dan lingkungan.

2. Respon Psikososial Meliputi :

1) Proses piker terganggu yang menimbulkan gangguan

2) Ilusi adalah miss intrerprestasi atau penilaian yang salah tentang yang benar-benar terjadi (objek nyata) karena gangguan panca indra

3) Emosi berlebihan atau kurang

4) Perilaku tidak biasa adalah sikap dan tingkah laku yang melebihi batas untuk menghindari Interaksi dengan orang lain

5) Menarik diri adalah percobaan untuk menghindari hubungan dengan orang lain.

b. Respon maladaptive adalah respon indikasi dalam menyelesaikan masalah yang menyimpang dari norma-norma social dan budaya dan lingkungan, adapun respon maladaptive ini meliputi :

1) Kelainan pikiran adalah keyakinan yang secara kokoh dipertahankan walaupun tidak diyakini oleh orang lain dan bertentangan dengan kenyataan sosail

2) Halusinasi merupakan persepsi sensori yang salah satu atau persepsi eksternal yang tidak realita atau tidak ada.

3) Kerusakan proses emosi adalah perubahan sesuatu yang timbul dari hati

4) Perilaku tak terorganisir merupakan perilaku yang tidak teratur 
5) Isolasi social adalah kondisi kesendirian yang dialami oleh individu dan diterima sebagai ketentuan oleh orang lain dan sebagai suatu kecelakaan yang negatif mengancam.

\subsubsection{Fase Halusinasi}

Halusinasi terbagi atas bebarapa fase (Oktiviani,2020):

\section{Fase pertama /sleep disorder}

Pada fase ini klien merasa banyak masalah,ingin menghindar dari lingkungan,takut diketahui orang lain bahwa dirinya banyak masalah. Masalah makin terasa sulit karna berbagai stressor terakumulasi, misalnya kekasih hamil, terlibat narkoba, dikhianati kekasih, masalah dikampus, drop out, dst. Masalah terasa menekan karena terakumulasi sedangkan support sistem kurang dan persepsi terhadap masalah sangat buruk. Sulit tidur berlangsung trus-menerus sehingga terbiasa menghayal. Klien menganggap lamunanlamunan awal tersebut sebagai pemecah masalah

\section{Fase Kedua / Comforting}

Klien mengalami emosi yang berlanjut seperti adanya perasaan cemas, kesepian, perasaan berdosa, ketakutan, dan mencoba memusatkan pemikiran pada timbulnya kecemasan. Ia beranggapan bahwa pengalaman pikiran dan sensorinya dapat dia kontrol bila kecemasannya diatur, dalam tahap ini ada kecenderungan klien merasa nyaman dengan halusinasinya

\section{Fase Ketiga / Condemning}

Pengalaman sensori klien menjadi sering datang dan mengalami bias. Klien mulai merasa tidak mampu lagi mengontrolnya dan mulai berupaya menjaga jarak antara dirinya dengan objek yang dipersepsikan klien mulai menarik diri dari orang lain, dengan intensitas waktu yang lama. 
4. Fase Keempat / Kontrolling Severe Level of Anxiety

Klien mencoba melawan suara-suara atau sensori abnormal yang datang. Klien dapat merasakan kesepian bila halusinasinya berakhir. Dari sinilah dimulai fase gangguan psikotik.

5. Fase ke lima / Conquering Panic Level of Anxiety Pengalaman sensorinya terganggu. Klien mulai terasa terancam dengan datangnya suara-suara terutama bila klien tidak dapat menuruti ancaman atau perintah yang ia dengar dari halusinasinya. Halusinasi dapat berlangsung selama minimal empat jam atau seharian bila klien tidak mendapatkan komunikasi terapeutik. Terjadi gangguan psikotik berat.

\subsubsection{Tanda Dan Gejala Halusinasi}

Tanda dan gejala gangguan persepsi sensori halusinasi yang dapat teramati sebagai berikut ( Dalami, 2016 ) :

a. Halusinasi penglihatan

1) Melirikkan mata ke kiri dan ke kanan seperti mencari siapa atau apa saja yang sedang dibicarakan.

2) Mendengarkan dengan penuh perhatian pada orang lain yang sedang tidak berbicara atau pada benda seperti mebel.

3) Terlihat percakapan dengan benda mati atau dengan seseorang yang tidak tampak.

4) Menggerakan-gerakan mulut seperti sedang berbicara atau sedang menjawab suara.

b. Halusinasi pendengaran

Adapun perilaku yang dapat teramati

1) Tiba-tiba tampak tanggap, ketakutan atau ditakutkan oleh orang lain, benda mati atau stimulus yang tidak tampak.

2) Tiba-tiba berlari keruangan lain 
c. Halusinasi penciuman

Perilaku yang dapat teramati pada klien gangguan halusinasi penciuman adalah :

1) Hidung yang dikerutkan seperti mencium bau yang tidak enak.

2) Mencium bau tubuh

3) Mencium bau udara ketika sedang berjalan ke arah orang lain.

4) Merespon terhadap bau dengan panik seperti mencium bau api atau darah.

5) Melempar selimut atau menuang air pada orang lain seakan sedang memadamkan api.

d. Halusinasi pengecapan

Adapun perilaku yang terlihat pada klien yang mengalami gangguan halusinasi pengecapan adalah :

1) Meludahkan makanan atau minuman.

2) Menolak untuk makan, minum dan minum obat.

3) Tiba-tiba meninggalkan meja makan.

e. Halusinasi perabaan

Perilaku yang tampak pada klien yang mengalami halusinasi perabaan adalah :

1) Tampak menggaruk-garuk permukaan kulit

Tanda dan gejala halusinasi dinilai dari hasil observasi terhadap klien serta ungkapan klien. Adapun tanda dan gejala klien halusinasi adalah sebagai berikut :

a) Data Subjektif Klien mengatakan :

1. Mendengar suara-suara atau kegaduhan

2. Mendengar suara yang mengajak bercakap-cakap

3. Mendengar suara menyuruh melakukan sesuatu yang berbahaya 
4. Melihat bayangan, sinar, bentuk geometris, bentuk kartun, melihat hantu dan monster

5. Mencium bau-bauan seperti bau darah, urin, feses, kadangkadang bau itu menyenangkan

6. Merasakan rasa seperti darah, urin dan feses

7. Merasa takutan atau senang dengan halusinasinya

b) Data Objektif

1. Bicara atau tertawa sendiri

2. Marah marah tanpa sebab

3. Mengarahkan telinga kearah tertentu

4. Menutup telinga

5. Menunjuk kearah tertentu

6. Ketakutan kepada sesuatu yang tidak jelas

7. Mencium sesuatu seperti sedang membaui bau-bauan tertentu

8. Menutup hidung Sering meludah Menggaruk garuk permukaan kulit

\subsection{Konsep Asuhan Keperawatan Jiwa}

\subsubsection{Pengkajian}

Pengkajian adalah proses untuk tahap awal dan dasar utama dari proes keperawatan terdiri dari pengumpulan data dan perumusan kebutuhan atau masalah klien. Data yang dikumpulkan melalui data biologis, psikologis, sosial dan spiritual. Pengelompokkan data pengkajian kesehatan jiwa, dapat berupa faktor presipitasi, penilaian terhadap stressor, sumber koping, dan kemampuan yang dimiliki (Afnuhazi, 2015) :

1. Identitas klien

Meliputi nama, umur, jenis kelamain, tanggal pengkajian, tanggal dirawat. 
2. Alasan masuk

Alasan klien datang ke RS biasanya klien sering berbicara sendiri, mendengar atau melihat sesuatu, suka berjalan tanpa tujuan, membanting peralatan dirumah, menarik diri.

3. Faktor predisposisi

1. Biasanya klien pernah mengalami gangguan jiwa dan kurang berhasil dalam pengobatan

2. Pernah mengalami aniaya fisik, penolakan dan kekerasan dalam keluarga

2. Klien dengan gangguan orientasi besifat herediter

3. Pernah mengalami trauma masa lalu yang sangat menganggu

4. Faktor Presipitasi

Stresor presipitasi pada klien dengan halusinasi ditemukan adanya riwayat penyakit infeksi, penyakt kronis atau kelaina stuktur otak, kekerasan dalam keluarga, atau adanya kegagalan kegagalan dalam hidup, kemiskinan, adanya aturan atau tuntutan dalam keluarga atau masyarakat yang sering tidak sesuai dengan klien serta konflik antar masyarakat.

5. Fisik

Tidak mengalami keluhan fisik.

6. Psikososial

a. Genogram Pada genogram

Biasanya terlihat ada anggota keluarga yang mengalami kelainan jiwa, pola komunikasi klien terganggu begitupun dengan pengambilan keputusan dan pola asuh.

b. Konsep diri

Gambaran diri klien biasanya mengeluh dengan keadaan tubuhnya, ada bagian tubuh yang disukai dan tidak disukai, identifikasi diri : klien biasanya mampu menilai identitasnya, peran diri klien menyadari peran sebelum sakit, saat dirawat peran klien terganggu, ideal diri tidak 
menilai diri, harga diri klien memilki harga diri yang rendah sehubungan dengan sakitnya.

c. Hubungan sosial

Klien kurang dihargai di lingkungan dan keluarga.

d. Spiritual

Nilai dan keyakinan biasanya klien dengan sakit jiwa dipandang tidak sesuai dengan agama dan budaya, kegiatan ibadah klien biasanya menjalankan ibadah di rumah sebelumnya, saat sakit ibadah terganggu atau sangat berlebihan.

\subsubsection{Diagnosa Keperawatan}

Dengan faktor berhubungan dan Batasan karakteristik disesuaikan dengan keadaan yang ditemukan pada tiap tiap partisipan. Topik yang diteliti yakni kemampuan mengontrol halusinasi dengar (Aji, 2019).

\subsubsection{Perancanaan Keperawatan}

Rencana tindakan pada keluarga (Keliat, 2016) adalah ;

1. Diskusikan masalah yang dihadap keluarga dalam merawat klien

2. Berikan penjelasan meliputi : pengertian halusinasi, proses terjadinya halusinasi, jenis halusinasi yang dialami, tanda dan gejala halusinasi, proses terjadinya halusinasi.

2. Jelaskan dan latih cara merawat anggota keluarga yang mengalami halusinasi : menghardik, minum obat, bercakap-cakap, melakukan aktivitas.

3. Diskusikan cara menciptakan lingkungan yang dapat mencegah terjadinya halusinasi.

4. Diskusikan tanda dan gejala kekambuhan

5. Diskusikan pemanfaatan fasilitas pelayanan kesehatan terdekat untuk follow up anggota keluarga dengan halusinasi. 


\subsubsection{Implementasi}

Implementasi disesuaikan dengan rencana tindakan keperawatan. Pada situasi nyata sering pelaksanaan jauh berbeda dengan rencana hal ini terjadi karena perawat belum terbiasa menggunakan rencana tertulis dalam melaksanakan tindakan keperawatan Dalami (2019). Adapun pelaksanaan tindakan keperawatan jiwa dilakukan berdasarkan Strategi Pelaksanaan (SP) yang sesuai dengan masing-masing maslaah utama.

Pada masalah Halusinasi Pendengaran: Halusinasi terdapat 4 macam SP yaitu :

SP 1 :- Diskusikan bersama klien tentang halusinasi (isi, frekuensi, waktu terjadi, situasi pencrtus,perasaan dan respon halusinasi)

- Mengajarkan klien menghardik

SP 2 : Mengontrol halusinasi dengan cara minum obat secara teratur SP 3 : Melatih bercakap cakap dengan oranng lain

SP 4 : Melatih melakukan kegiatan terjadwal

\subsubsection{Evaluasi Keperawatan}

Evaluasi adalah proses hasil atau sumatif dilakukan dengan membandingkan respon klien pada tujuan umum dan tujuan khusus yang telah ditentukan.halusinasi pendengaran tidak terjadi perilaku kekerasan, klien dapat membina hubungan saling percaya, klien dapat mengenal halusinasinya, klien dapat mengontrol halusinasi dengar dari jangka waktu 4x24 jam didapatkan data subjektif keluarga menyatakan senang karena sudah diajarkan teknik mengontrol halusinasi, keluarga menyatakan klien mampu melakukan beberapa teknik mengontrol halusinasi. Data objektif klien tampak berbicara sendiri saat halusinasi itu datang, klien dapat berbincang-bincang dengan orang lain, klien mampu melakukan aktivitas terjadwal, dan minum obat secara teratur ( Aji, 2019 ) 


\section{BAB 3}

TINJAUAN KASUS

RUANG RAWAT : Sibual Buali

TANGGAL RAWAT : 14-11-2021

\subsection{Identitas Klien}

Inisial

Tanggal pengkajian

Umur

MR No.

Informan
: Tn.L

: 27 Januari 2022

$: 41$ th

: 03.81 .48

: Rekam medik dan komunikasi dengan klien

\subsection{Alasan Masuk}

Klien sebelumnya pernah di rawat di RSJ 1 tahun yang lalu, kembali lagi karena tidak rutin kontrol dan tidak patuh minum obat, Klien meresahkan warga sekitar. Klien pernah menikah 2 kali namun bercerai karena Tn.L tidak mampu menafkahi istrinya Dan ingin menikah lagi tetapi gagal. Klien mendengar suara-suara tanpa wujud, suara tersebut adalah suara ibu mertuanya yang menyuruhnya pergi. Klien merasa kesal karena suara tersebut selalu datang dan tekadang tidak mampu menahan amarahnya.

\subsection{Faktor Predisposisi}

Klien sebelumnya tidak pernah mengalami gangguan jiwa, Klien pernah menikah 2 kali namun bercerai karena tidak mampu menafkahinya. Ingin menikah lagi namun gagal.

Klien pernah memukuli ibunya sebelum masuk ke RSJ.

\subsection{Fisik}

Klien tidak memiliki keluhan fisik, saat dilakukan pemeriksaan tanda-tanda vital, didapatkan hasil:
- $\quad$ TD TD : $137 / 79 \mathrm{mmHg}$
- BB: 68 
- $\quad \mathrm{N}: 195 \mathrm{x} / \mathrm{I}$

- TB: 167

- $\quad \mathrm{S}: 36,1^{\circ} \mathrm{C}$

- $\quad P: 21 x / 1$

\subsection{Psikososial}

\subsubsection{Genogram}

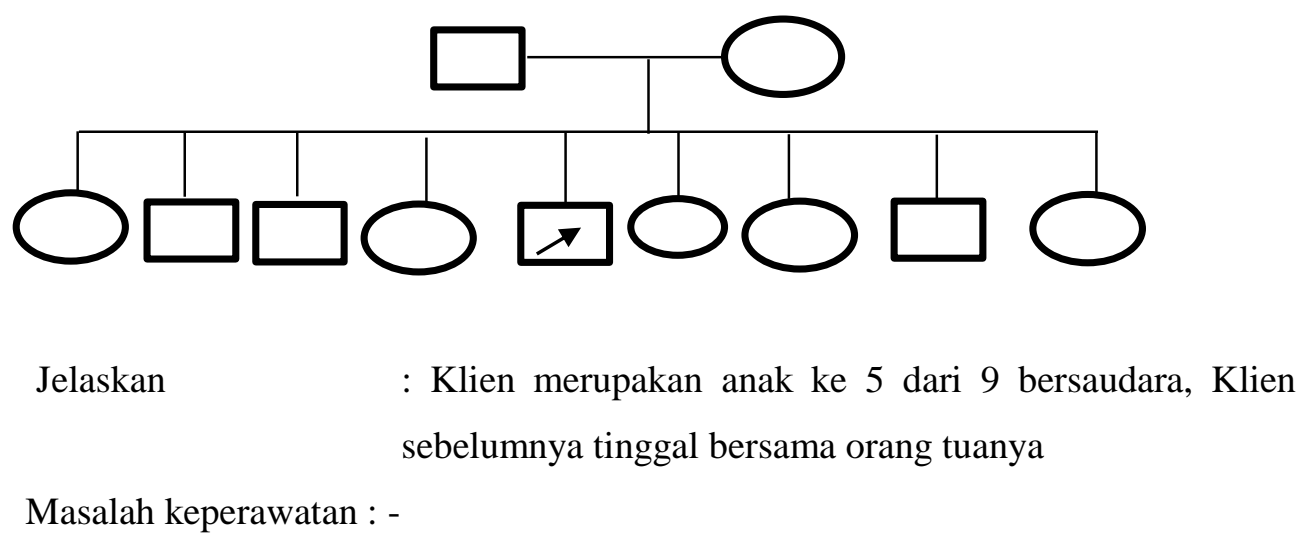

\subsubsection{Konsep Diri}

1. Gambaran Diri :Klien mengatakan menyukai seluruh bagian tubuhnya

2. Identitas :Klien dapat mengetahui nama dan alamatnya

3. Peran :Klien sadar belum memenuhi perannya sebagai suami

4. Ideal diri :Klien merasa malu karena masa lalunya, dan klien tidak ingin pulang kerumah, dan lebih suka di rumah sakit. Karena jika pulang klien malu karena penyakitnya.

5. Harga diri :Klien merasa malu karena gagal menjadi suami, dan malu akan penyakitnya

Masalah keperawatan: Gangguan konsep diri : Harga diri rendah kronik

\subsubsection{Hubungan Sosial}

1. Orang yang berarti : Orang tua

2. Peran serta dalam kegiatan kelompok/masyarakat: Aktif 
3. Hambatan dalam berhubungan dengan orang lain: Klien tidak memiliki hambatan dalam berhubungan dengan orang lain

Masalah Keperawatan : : -

\subsubsection{Spiritual}

1. Nilai dan keyakinan : klien beragama Islam, percaya akan keyakinannya, berharap keluarga dan masyarakat mau menerima keadaanya.

2. Kegiatan ibadah : Tidak pernah ibadah

Masalah Keperawatan : Defisit Spiritual

\subsubsection{Status Mental}

a. Penampilan

Penjelasan :Klien berpenampilan bersih, rapi, dan menggunakan pakaian yang di berikan oleh keluarganya.

b. Pembicaraan

Penjelasan :Klien masih mampu menjawab pertanyaan yang di berikan.

c. Suasana perasaan

Penjelasan : : Klien merasa khawatir karena penyakitnya, malu jika pulang kerumah dan akan di kucilkan oleh lingkungannya.

d. Interaksi selama wawancara

Penjelasan :Klien kooperatif, ada kontak mata pada lawan bicara, mudah tersinggung dalam setiap interaksi.

e. Persepsi

Penjelasan :Mendengar suara-suara bisikan tanpa wujud, Yaitu suara mertuanya yang menyuruhnya pergi, suara 
muncul ketika sedang termenung dan pada saat maghrib.

Masalah keperawatan : Halusinasi Pendengaran

f. Proses Pikir

Penjelasan :Klien mampu menjawab pertanyaan dengan baik, namun terkadang harus ada pengulangan pertanyaan

g. Isi piker

Penjelasan :Klien dapat mengontrol isi pikirnya, klien tidak mengalami gangguan isi pikir dan tidak ada waham.

h. Tingkat kesadaran

Penjelasan :Klien sadar penuh

i. Memori

Penjelasan :Klien mampu menceritakan kejadian di masa lalu dan yang baru terjadi.

j. $\quad$ Tingkat konsentrasi berhitung

Penjelasan :Klien mampu menjawab namun kurang berkonsentrasi

k. Kemampuan penilaian

Penjelasan :Klien dapat membedakan hal yang baik dan yang buruk.

1. Daya tilik diri

Penjelasan :Klien tidak mengingkari penyakit yang diderita, klien mengetahui bahwa dia sering mendengar suara-suara bisikan

\subsection{Mekanisme Koping}

Klien mengalami mekanisme koping adaptif yaitu klien dapat berbicara baik dengan orang lain dan kooperatif. 


\subsection{Masalah Psikososial dan Lingkungan}

Klien mengatakan pernah menikah 2 kali kemudian bercerai karena tidak mampu menafkahi istrinya, dan akan menikah lagi namun gagal.

Klien pernah memukul ibunya karena selalu bertanya kepadanya.

Klien pernah berkelahi (memukul temannya Tn.R) karena tidak mau menuruti perkataannya.

\subsection{Pengetahuan Kurang Tentang}

Klien mengetahui tentang gangguan jiwa yang di alaminya, klien mengatakan jika sedang mendengar suara-suara bisikan maka menutup telinga

\subsection{Aspek Medik}

Diagnosa Medik :

Skizofrenia paranoid

Terapi Medik: Pemberian/minum obat kepada klien secara teratur.
a. Risperidon (RSP) tablet $2 \mathrm{mg} 2 \mathrm{x} 1$.
b. clozapine $25 \mathrm{mg} 1 \mathrm{x} 1$ 


\subsection{ANALISIS DATA}

\begin{tabular}{|c|c|c|}
\hline No & Data & Masalah Keperawatan \\
\hline 1 & $\begin{array}{l}\text { Data Subjektif: } \\
\text { Klien mengatakan sering mendengar suara-suara } \\
\text { tanpa wujud, Suara tersebut adalah suara ibu } \\
\text { mertuanya yang menyuruhnya untuk pergi, Suara } \\
\text { tersebut muncul saat maghrib } \\
\text { Data Objektif: } \\
\text { 1.Klien tampak sering bicara-bicara sendiri seperti } \\
\text { ada dunianya } \\
\text { 2.Klien tampak gelisah } \\
\text { 3.Klien tampak senyum-senyum } \\
\text { 4.Klien bicara ngawur }\end{array}$ & Halusinasi Pendengaran \\
\hline 2 & $\begin{array}{l}\text { Data Subjektif: } \\
\text { Klien mengatakan pernah memukul ibunya } \\
\text { sebelum kembali masuk rsj karena terlalu banyak } \\
\text { bertanya, Klien pernah berkelahi (memukul } \\
\text { temannya) karena tidak mau menuruti } \\
\text { perkataannya } \\
\text { Klien mendengar suara-suara tanpa wujud, Klien } \\
\text { mengatakan sering ingin marah saat mendengar } \\
\text { suara tersebut, pernah melempar barang-barang } \\
\text { yang ada dirumahnya. } \\
\text { Data Objektif: } \\
\text { Klien mengamuk, Tangan mengepal saat marah, } \\
\text { Merusak barang }\end{array}$ & $\begin{array}{c}\text { Risiko Perilaku } \\
\text { Kekerasan }\end{array}$ \\
\hline
\end{tabular}




\begin{tabular}{|l|l|l|}
\hline 3 & Data Subjektif: & Gangguan Konsep Diri: \\
Klien merasa malu karena mempunyai sakit ini. & Harga diri rendah kronik \\
Klien mengatakan tidak berguna karena gagal \\
menjadi suami yang tidak mampu menafkahi \\
istrinya, Klien tidak mau kembali kerumah \\
karena takut di kucilkan oleh tetangganya. \\
Data Objektif: \\
1. Klien tampak sedih \\
2. Klien tampak mudah tersinggung \\
3. klien tampak bingung \\
4. klien tampak menyendiri
\end{tabular}

\subsection{DAFTAR MASALAH KEPERAWATAN}

a. Resiko Perilaku Kekerasan

b. Halusinasi Pendengaran

c. Gangguan Konsep Diri : Harga diri rendah kronik

\subsection{POHON MASALAH}

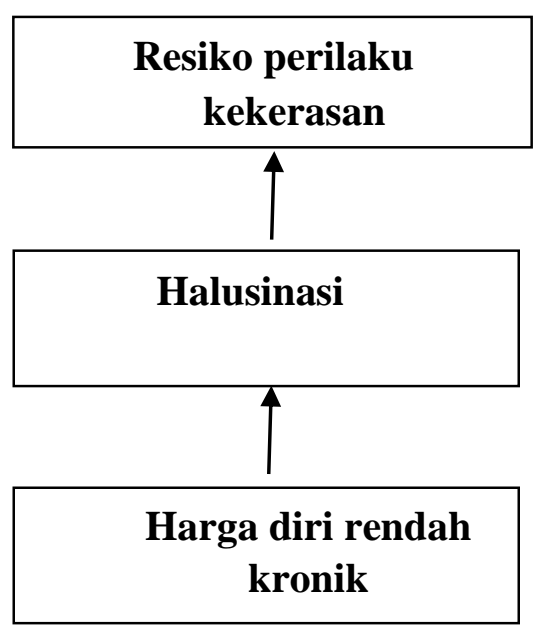




\subsection{DAFTAR DIAGNOSIS KEPERAWATAN}

1. Halusinasi Pendengaran

2. Prilaku kekerasan

3. Harga Diri Rendah Kronik

\subsection{INTERVENSI KEPERAWATAN}

\begin{tabular}{|c|c|c|c|}
\hline $\begin{array}{c}\text { Diagnosa } \\
\text { Keperawatan }\end{array}$ & Tujuan & Kriteria Hasil & Intervensi \\
\hline \multirow[t]{2}{*}{$\begin{array}{c}\text { Halusinasi } \\
\text { Pendengaran }\end{array}$} & $\begin{array}{l}\text { Klien dapat membina } \\
\text { hubungan saling } \\
\text { percaya }\end{array}$ & $\begin{array}{l}\text { Ketika di evaluasi Klien mau } \\
\text { membalas salam, berjabat tangan, } \\
\text { menyebutkan nama, tersenyum, ada } \\
\text { kontak mata,serta menyediakan waktu } \\
\text { untuk kunjunganberikutnya }\end{array}$ & $\begin{array}{l}\text { a. Membina hubungan saling } \\
\text { percaya dengan cara } \\
\text { (menjelaskan maksud dan } \\
\text { tujuan interaksi, jelaskan } \\
\text { tentang kontrak yang akan } \\
\text { dibuat, beri rasa aman dan } \\
\text { sikap empati) }\end{array}$ \\
\hline & $\begin{array}{l}\text { Klien paham dan } \\
\text { mampu } \\
\text { mengendalikan } \\
\text { halusinasi dengan } \\
\text { cara mempraktikan } \\
\text { cara menghardik }\end{array}$ & $\begin{array}{lrr}\text { Klien paham dan } & \text { mampu } \\
\text { memahami halusinasi } & \text { dan } \\
\text { mengendalikan halusinasi } & \text { dengan } \\
\text { cara mempraktikan } & \text { cara } \\
\text { menghardik } & \end{array}$ & $\begin{array}{l}\text { Sp } 1 \\
\text { 1. Diskusikan bersama klien } \\
\text { tentang halusinasi (isi, } \\
\text { frekuensi, waktu terjadi, } \\
\text { situasi pencetus, perasaan, } \\
\text { dan respon halusinasi) }\end{array}$ \\
\hline
\end{tabular}




\begin{tabular}{|c|c|c|c|}
\hline & & & 2. Latih klien cara menghardik \\
\hline & $\begin{array}{l}\text { Klien paham dan } \\
\text { mau minum obat } \\
\text { secara teratur }\end{array}$ & $\begin{array}{l}\text { Klien paham dan mau minum obat } \\
\text { secara teratur }\end{array}$ & $\begin{array}{l}\text { Sp } 2 \\
\text { Latih klien minun obat secara } \\
\text { teratur }\end{array}$ \\
\hline & $\begin{array}{l}\text { Klien paham dan } \\
\text { mampu } \\
\text { mengendalikan } \\
\text { halusinasi dengan } \\
\text { cara bercakap-cakap } \\
\text { dengan orang lain }\end{array}$ & $\begin{array}{l}\text { Klien paham dan mampu } \\
\text { mengendalikan halusinasi dengan } \\
\text { cara bercakap-cakap dengan orang } \\
\text { lain }\end{array}$ & $\begin{array}{l}\text { Sp } 3 \\
\text { Latih klien bercakap-cakap } \\
\text { dengan orang lain }\end{array}$ \\
\hline & $\begin{array}{l}\text { Klien paham dan } \\
\text { mampu } \\
\text { mengendalikan } \\
\text { halusinasi dengan } \\
\text { cara melakukan } \\
\text { kegiatan terjadwal }\end{array}$ & $\begin{array}{l}\text { Klien paham dan mampu } \\
\text { mengendalikan halusinasi dengan } \\
\text { cara melakukan kegiatan terjadwal }\end{array}$ & $\begin{array}{l}\text { Sp } 4 \\
\text { Latih klien melakukan kegiatan } \\
\text { terjadwal }\end{array}$ \\
\hline $\begin{array}{l}\text { Perilaku } \\
\text { Kekerasan }\end{array}$ & $\begin{array}{lr}\text { klien dapat } & \text { membina } \\
\text { hubungan } & \text { saling } \\
\text { percaya } & \end{array}$ & $\begin{array}{l}\text { Ketika di evaluasiKlien mau } \\
\text { membalas salam, berjabat tangan, } \\
\text { menyebutkan nama, tersenyum, } \\
\text { ada kontak mata,serta } \\
\text { menyediakan waktuuntuk } \\
\text { kunjunganberikutnya }\end{array}$ & $\begin{array}{l}\text { 1. Bina hubungan saling } \\
\text { percaya dengan cara } \\
\text { (menjelaskan maksud } \\
\text { dan tujuan interaksi, } \\
\text { jelaskan tentang kontrak } \\
\text { yang akan dibuat, beri } \\
\text { rasa aman dan sikap } \\
\text { empati) } \\
\text { Diskusikan bersama klien } \\
\text { tentang perilaku kekerasan } \\
\text { (penyebab, tanda dan gejala, } \\
\text { perilaku yang muncul dan }\end{array}$ \\
\hline
\end{tabular}




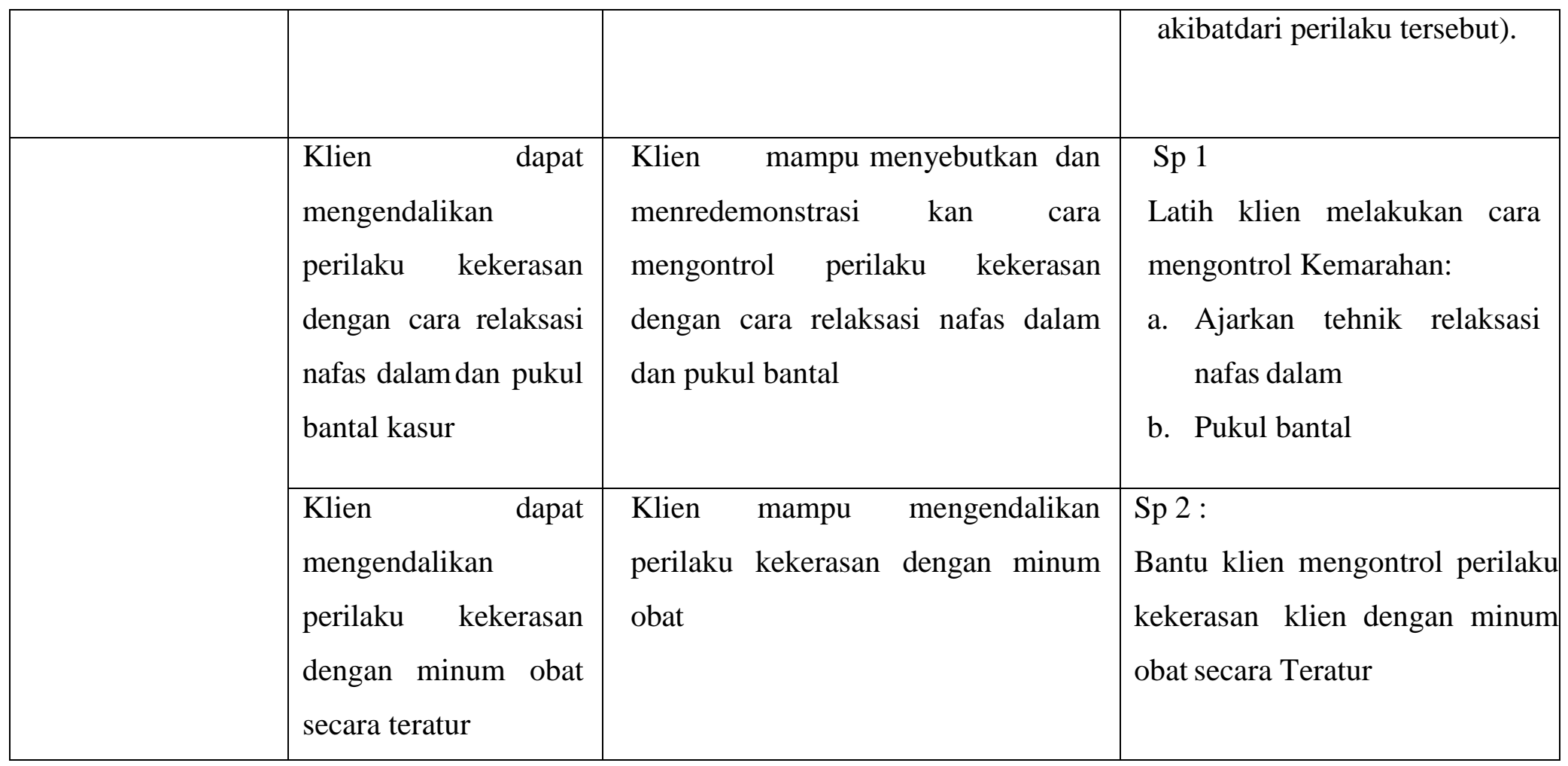




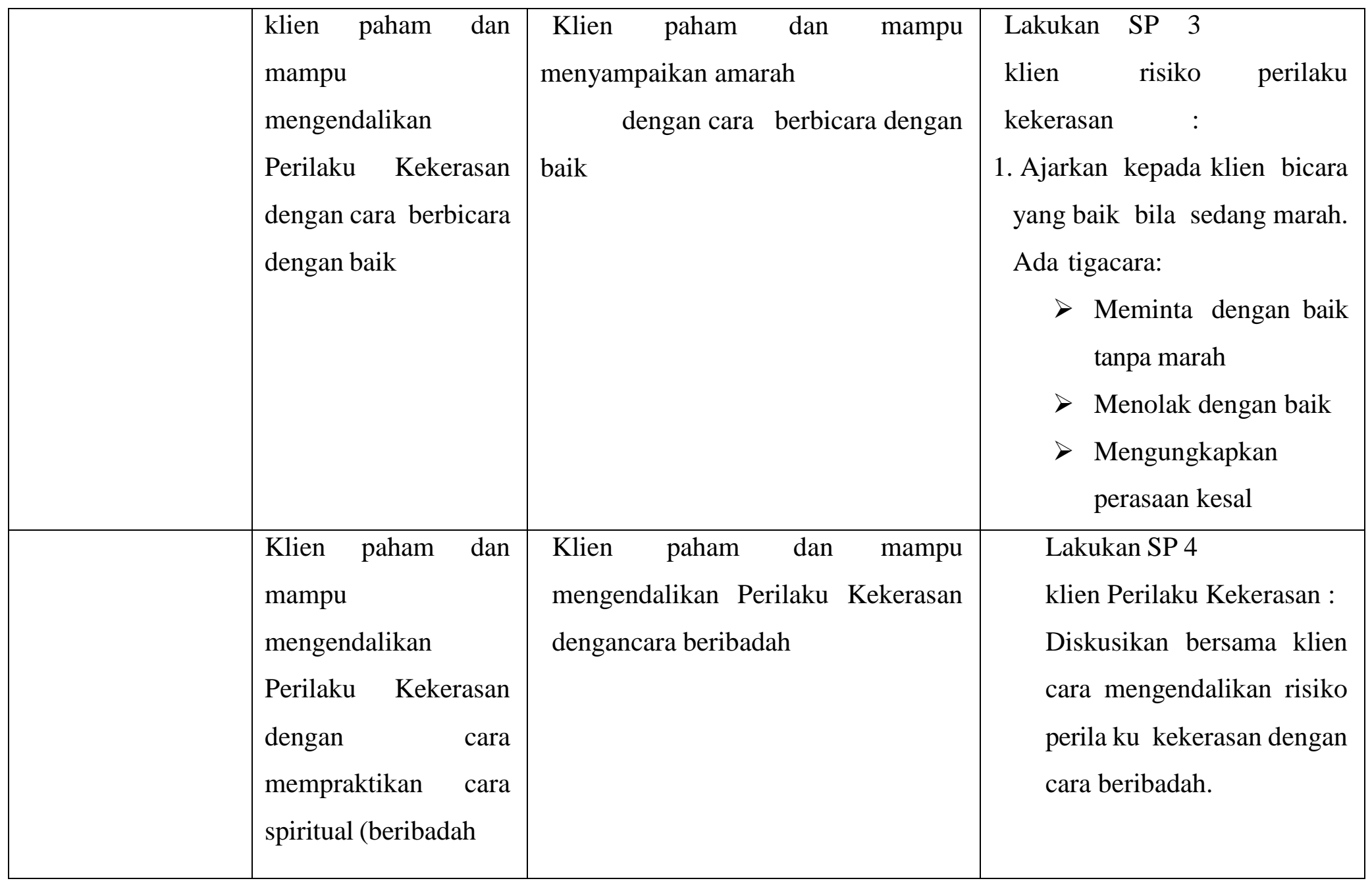




\begin{tabular}{|c|c|c|c|}
\hline $\begin{array}{c}\text { Harga Diri Rendah } \\
\text { Kronik }\end{array}$ & $\begin{array}{l}\text { Klien paham dan } \\
\text { mampu } \\
\text { mengindentifikasi } \\
\text { kemampuan positif } \\
\text { yang dimiliki }\end{array}$ & $\begin{array}{l}\text { Klien paham dan mampu } \\
\text { mengindentifikasi } \\
\text { positif yang dimiliki }\end{array}$ & $\begin{array}{l}\text { Sp } 1 \\
\text { Diskusikan bersama klien } \\
\text { tentang kemampuan positif } \\
\text { yang dimiliki }\end{array}$ \\
\hline & $\begin{array}{l}\text { Klien paham dan } \\
\text { mampu menilai } \\
\text { kemampuan yang } \\
\text { dapat digunakan }\end{array}$ & $\begin{array}{l}\text { Klien paham dan mampu menilai } \\
\text { kemampuan yang dapat digunakan }\end{array}$ & $\begin{array}{l}\text { Sp } 2 \\
\text { 1. Bantu klien menilai } \\
\text { kemampuan yang dapat } \\
\text { digunakan } \\
\text { 2. Bantu klien menetapkan } \\
\text { kemampuan yang dapat } \\
\text { digunakan } \\
\text { 3. Melatih kegiatan sesuai } \\
\text { kemampuan yang dipilih } 1\end{array}$ \\
\hline
\end{tabular}




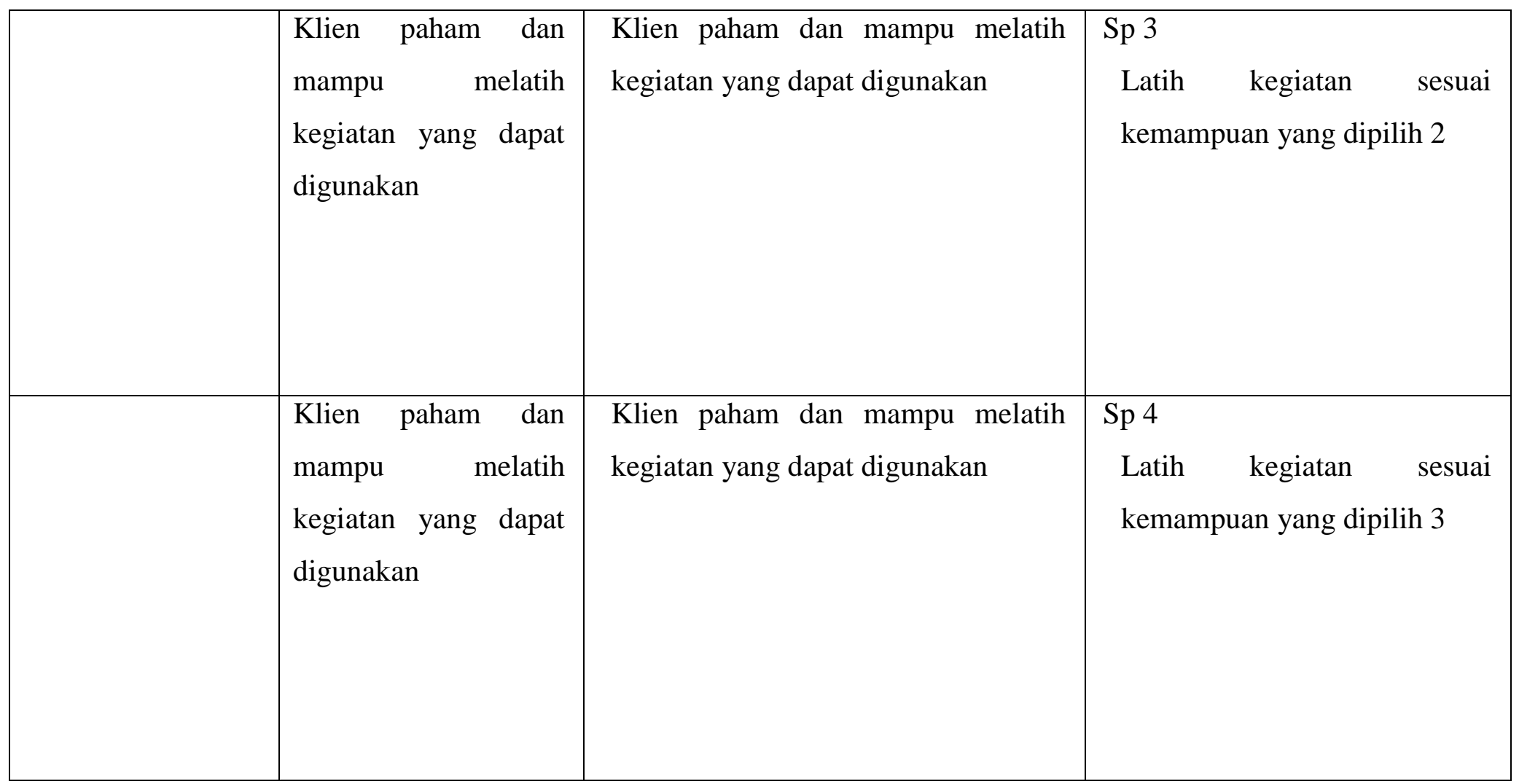


3.15 IMPLEMENTASI DAN EVALUASI KEPERAWATAN

\begin{tabular}{|c|c|c|}
\hline Hari/tgl & Implementasi & Evaluasi \\
\hline $\begin{array}{c}\text { Kamis, } 27 \\
\text { Januari } 2022\end{array}$ & $\begin{array}{l}\text { 1. Data: } \\
\text { Tanda dan gejala :Berbicara sendiri, Mendengar suara- } \\
\text { suara, Menutup telinga } \\
\text { 2.Diagnosa Keperawatan : } \\
\text { Halusinasi pendengaran } \\
\text { 3.Tindakan keperawatan } \\
\text { Sp } 1 \text { Halusinasi pendengaran } \\
\text { 1. Mengidentifikasi isi, frekuensi, waktu terjadi, situasi } \\
\text { pencetus, perasaan dan respon halusiasi } \\
\text { 2. Melatih cara Menghardik } \\
\text { 4. RTL: } \\
\text { Sp } 2 \text { Halusinasi Pedengaran } \\
\text { 1. Minum obat secara teratur }\end{array}$ & $\begin{array}{l}\text { S: } \\
\text { klien mengatakan masih mendengar suara- } \\
\text { suara aneh yang berbisik pada saat } \\
\text { maghrib } \\
\text { O: } \\
\text { - klien tampak berbicara tidak jelas } \\
\text { - Klien mampu menghardik } \\
\text { A:Halusinasi Pendengaran (+) } \\
\text { P : } \\
\text {-Mengidentifikasi isi, frekuensi, waktu } \\
\text { terjadi, situasi pencetus, perasaan dan } \\
\text { respon halusinasi } \\
\text {-Menghardik 3x1 }\end{array}$ \\
\hline $\begin{array}{l}\text { Jum'at, } 28 \\
\text { januari } 2022\end{array}$ & $\begin{array}{l}\text { 1. Data: } \\
\text { Tanda dan gejala :Berbicara sendiri, Mendengar suara- } \\
\text { suara, Menutup telinga } \\
\text { 2. Diagnosa Keperawatan : } \\
\text { Halusinasi pendengaran } \\
\text { 3. Tindakan keperawatan } \\
\text { Sp } 2 \text { Halusinasi pendengaran } \\
\text {. Minum Obat teratur }\end{array}$ & $\begin{array}{l}\text { S: } \\
\text { - Senang, bersemangat } \\
\text { - klien mengatakan masih mendengar } \\
\quad \text { suara-suara tersebut } \\
\text { O: } \\
\text { - klien tampak berbicara berbicara sendiri } \\
\text { - klien mampu minum obat secara teratur } \\
\text { A:Halusinasi Pendengaran }(+)\end{array}$ \\
\hline
\end{tabular}




\begin{tabular}{|c|c|c|}
\hline & $\begin{array}{l}\text { 4. RTL: } \\
\text { Sp } 3 \text { Halusinasi Pedengaran } \\
\text { 1. Bercakap-cakap dengan orang lain }\end{array}$ & $\begin{array}{l}\text { P : } \\
\text {-Menghardik 3x1 } \\
\text {-Minum obat } \\
\text { Risperidone } 2 \times 1 \\
\text { Clozapine 1x1 }\end{array}$ \\
\hline $\begin{array}{l}\text { Senin, } 31 \\
\text { januari } 2022\end{array}$ & $\begin{array}{l}\text { 1. Data: } \\
\text { Tanda dan gejala :Berbicara sendiri, Mendengar suara- } \\
\text { suara, Menutup telinga } \\
\text { 2. Diagnosa Keperawatan : } \\
\text { Halusinasi pendengaran } \\
\text { 3. Tindakan keperawatan } \\
\text { Sp } 3 \text { Halusinasi pendengaran } \\
\text { 1. Evaluasi pengetahuan dan kepatuhan minum obat } \\
\text { 2. Bercakap-cakap dengan orang lain } \\
\text { 4. RTL: } \\
\text { Sp4 halusinasi pendengaran } \\
\text { 1. Melakukan Kegiatan terjadwal }\end{array}$ & $\begin{array}{l}\text { S: } \\
\text { klien mengatakan suara suara mulai } \\
\text { berkurang } \\
\text { O: } \\
\quad \text { - Klien mengetahui manfaat obat } \\
\quad \text { - Klien mampu bercakap-cakap } \\
\quad \text { dengan orang lain } \\
\text { A:Halusinasi Pendengaran (+) } \\
\text { P : } \\
\text {-Mengidentifikasi isi, frekuensi, waktu } \\
\text { terjadi, situasi pencetus, perasaan dan } \\
\text { respon halusinasi } \\
\text {-Menghardik } 3 \times 1 \\
\text {-Minum obat } \\
\text { Risperidone } 2 \times 1 \\
\text { Clozapine } 1 \times 1\end{array}$ \\
\hline
\end{tabular}




\begin{tabular}{|c|c|c|}
\hline & $\begin{array}{l}\text { 1. Data: } \\
\text { Tanda dan gejala :Berbicara sendiri, Mendengar } \\
\text { suara-suara, Menutup telinga } \\
\text { 2. Diagnosa Keperawatan : } \\
\text { Halusinasi pendengaran } \\
\text { 3. Tindakan keperawatan } \\
\text { Sp } 4 \text { Halusinasi pendengaran } \\
\text { 1. Melakukan Kegiatan terjadwal } \\
\text { 4. RTL: } \\
\text { Evaluasi Sp1-Sp4 }\end{array}$ & $\begin{array}{l}\text { S: } \\
\text { Klien merasa senang } \\
\text { O: } \\
\text { Klien melakukan kegiatan terjadwal } \\
\text { A:Halusinasi Pendengaran (+) } \\
\text { P : } \\
\text {-Menghardik } 3 \times 1 \\
\text {-Minum obat } \\
\text { Risperidone } 2 \times 1 \\
\text { Clozapine } 1 \times 1 \\
\text { - Melakukan kegiatan terjadwal }\end{array}$ \\
\hline $\begin{array}{l}\text { Rabu, } 02 \\
\text { februari } 2022\end{array}$ & $\begin{array}{l}\text { 1. Data: } \\
\text { Tanda dan gejala :Berbicara sendiri, Mendengar } \\
\text { suara-suara, Menutup telinga } \\
\text { 2. Diagnosa Keperawatan : } \\
\text { Halusinasi pendengaran } \\
\text { 3. Tindakan keperawatan } \\
\text { Sp Halusinasi pendengaran } \\
\text { Evaluasi Sp1-Sp4 }\end{array}$ & $\begin{array}{l}\text { S: } \\
-\quad \text { Klien merasa senang } \\
-\quad \text { Klien mengatakan sudah jarang } \\
\text { mendengar suara suara } \\
\text { O: } \\
\text { Klien melakukan kegiatan terjadwal } \\
\text { A:Halusinasi Pendengaran (+) } \\
\text { P : } \\
\text {-Menghardik } 3 \times 1 \\
\text {-Minum obat } \\
\text { Risperidone } 2 \times 1 \\
\text { Clozapine } 1 \times 1\end{array}$ \\
\hline
\end{tabular}




\begin{tabular}{|c|c|c|}
\hline & & - Melakukan kegiatan terjadwal \\
\hline $\begin{array}{l}\text { Kamis, } 03 \\
\text { februari } 2022\end{array}$ & $\begin{array}{l}\text { 1. Data : } \\
\text { Tanda dan gejala : mudah marah- marah, mudah } \\
\text { tersinggung, Suara keras, Jika kesal tangan mengepal } \\
\text { 2. Diagnosa Keperawatan : } \\
\text { Resiko Perilaku Kekerasan } \\
\text { 3. Tindakan keperawatan: } \\
\text { Sp } 1 \text { Resiko Perilaku Kekerasan: } \\
\text { - Mengidentifikasi penyebab Perilaku Kekerasan } \\
\text { yaitu jika tidak ada yang mendengarnya } \\
\text { - Mengidentifikasi tanda dan gejala Perilaku } \\
\text { Kekerasan yaitu klien marah, mengamuk tanpa jelas, } \\
\text { memukul orang lain } \\
\text { Melatih klien cara mengontrol Perilaku Kekerasan } \\
\text { dengan cara: } \\
\text { Latihan fisik } 1 \text { : Tarik nafas dalam } \\
\text { Latihan fisik } 2 \text { : pukul kasur bantal } \\
\text { 4. RTL: } \\
\text { Sp2 Perilaku Kekerasan: } \\
\text { - Mengontrol Resiko Perilaku Kekerasan dengan } \\
\text { minum obat secara teratur }\end{array}$ & $\begin{array}{l}\text { S : antusias dan bersemangat } \\
\text { O : } \\
\text { - Klien mampu melakukan latihan fisik 1: } \\
\text { tarik nafas dalam secara mandiri } \\
\text { - Klien mampu pukul kasur bantal dengan } \\
\text { mandiri } \\
\text { A :Resiko Perilaku Kekerasan(+) } \\
\text { P : Latihan fisik: } \\
\text { - Tarik nafas dalam } 3 \mathrm{x} / \text { hari } \\
\text { - Pukul kasur bantal } 1 \mathrm{x} / \text { hari }\end{array}$ \\
\hline
\end{tabular}




\begin{tabular}{|c|c|c|}
\hline $\begin{array}{l}\text { Jum'at } 04 \\
\text { februari } 2022\end{array}$ & $\begin{array}{l}\text { 1. Data : } \\
\text { Tanda dan gejala : mudah marah- marah, mudah } \\
\text { tersinggung, Suara keras, Jika kesal tangan mengepal } \\
\text { depan rumah } \\
\text { 2. Diagnosa Keperawatan : } \\
\text { Resiko Perilaku Kekerasan } \\
\text { 3. Tindakan keperawatan: } \\
\text { Sp } 2 \text { Perilaku Kekerasan } \\
\text { 1. Mengevaluasi kemampuan klien untuk tarik } \\
\text { nafas dan pukul kasur bantal } \\
\text { 2. Memberikan informasi tentangpenggunaan obat } \\
\text { RTL: } \\
\text { Sp } 3 \text { Perilaku Kekerasan } \\
\text { - Komunikasi secara verbal:Asertif/bicara baik- } \\
\text { baik. }\end{array}$ & 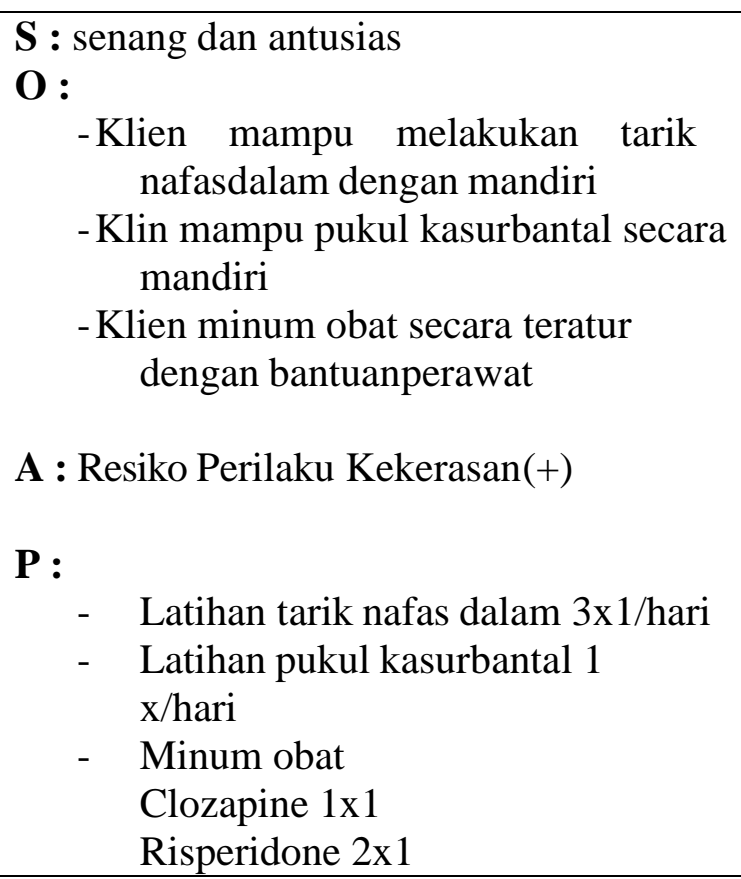 \\
\hline $\begin{array}{l}\text { Sabtu, } 05 \\
\text { februari } 2022\end{array}$ & $\begin{array}{l}\text { 1. Data : } \\
\text { Tanda dan gejala : mudah marah- marah, mudah } \\
\text { tersinggung, Suara keras, Jika kesal tangan mengepal } \\
\text { 2. Diagnosa Keperawatan: } \\
\text { Resiko Perilaku Kekerasan } \\
\text { 3. Tindakan keperawatan: } \\
\text { Sp } 3 \text { Perilaku Kekerasan } \\
\text { 1. } \text { Mengevaluasi pengetahuan klien tentang obat } \\
\text { 2. } \text { Melatih klien komunikasi secara verbal : Asertif/bicara }\end{array}$ & 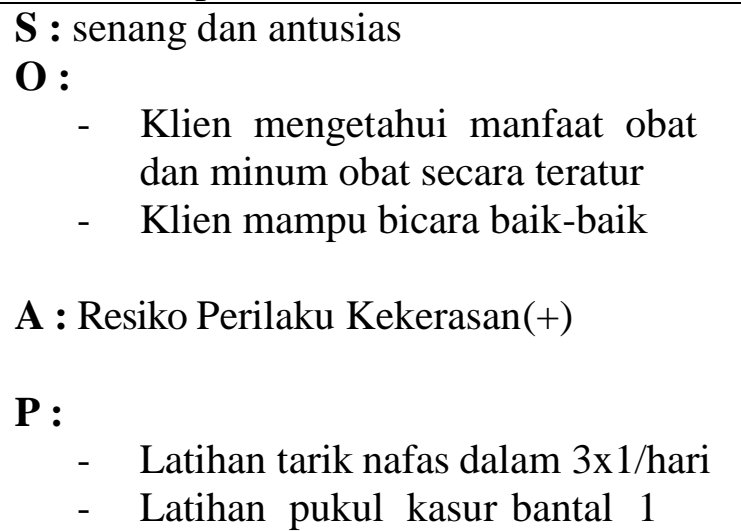 \\
\hline
\end{tabular}




\begin{tabular}{|c|c|c|}
\hline & $\begin{array}{l}\text { baik-baik } \\
\text { RTL: } \\
\text { Sp } 4 \text { Perilaku Kekerasan } \\
\text { 1. Melatih Spiritual. }\end{array}$ & $\begin{array}{l}\mathrm{x} / \mathrm{h} \text { ari } \\
\text { Minum obat } \\
\text { Clozapine } 1 \mathrm{x} 1 \\
\text { Risperidone } 2 \mathrm{x} 1\end{array}$ \\
\hline $\begin{array}{l}\text { Senin, } 07 \\
\text { februari } 2022\end{array}$ & $\begin{array}{l}\text { 1. Data : } \\
\text { Tanda dan gejala : mudah marah- marah, mudah } \\
\text { tersinggung, Suara keras, Jika kesal tangan mengepal } \\
\text { 2. Diagnosa Keperawatan } \\
\text { Resiko Perilaku Kekerasan } \\
\text { 3. Tindakan keperawatan: } \\
\text { Sp } 4 \text { Perilaku Kekerasan } \\
\text { 1. Mengevaluasi cara bicara klien } \\
\text { 2. Melatih spiritual } \\
\text { RTL: } \\
\text { Evaluasi Sp1-Sp4 }\end{array}$ & 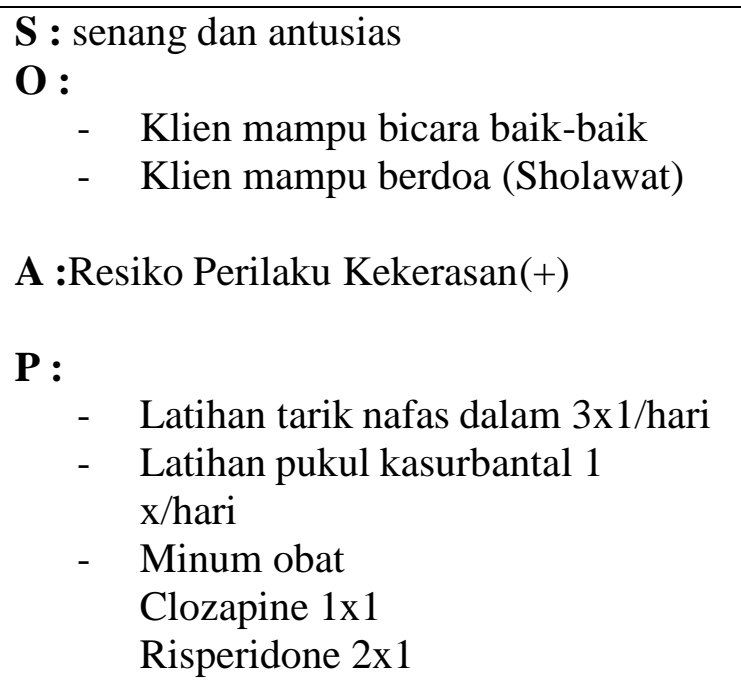 \\
\hline $\begin{array}{l}\text { Selasa, } 08 \\
\text { februari } 2022\end{array}$ & $\begin{array}{l}\text { 1. Data : } \\
\text { Tanda dan gejala : mudah marah- marah, mudah } \\
\text { tersinggung, Suara keras, Jika kesal tangan } \\
\text { mengepal Kemampuan : berjualan depan rumah } \\
\text { 2. Diagnosa Keperawatan } \\
\text { Resiko Perilaku Kekerasan } \\
\text { 3. } \text { Tindakan keperawatan: } \\
\text { Sp Perilaku Kekerasan } \\
\text { Evaluasi Sp1-Sp4 }\end{array}$ & $\begin{array}{ll}\text { S : } & \text { senang dan antusias } \\
\text { O : } & \text { Klien mampumelakukan } \\
& \text { - } \\
& \text { latihan fisik tarik nafas dalam } \\
& \text { dengan mandiri } \\
\text { - } & \text { Klien mampu pukul kasur bantal } \\
& \text { dengan mandiri } \\
\text { - } & \text { Klien mengetahui manfaat obat } \\
& \text { dan minum obat secara teratur } \\
\end{array}$ \\
\hline
\end{tabular}




\begin{tabular}{|c|c|c|}
\hline & & 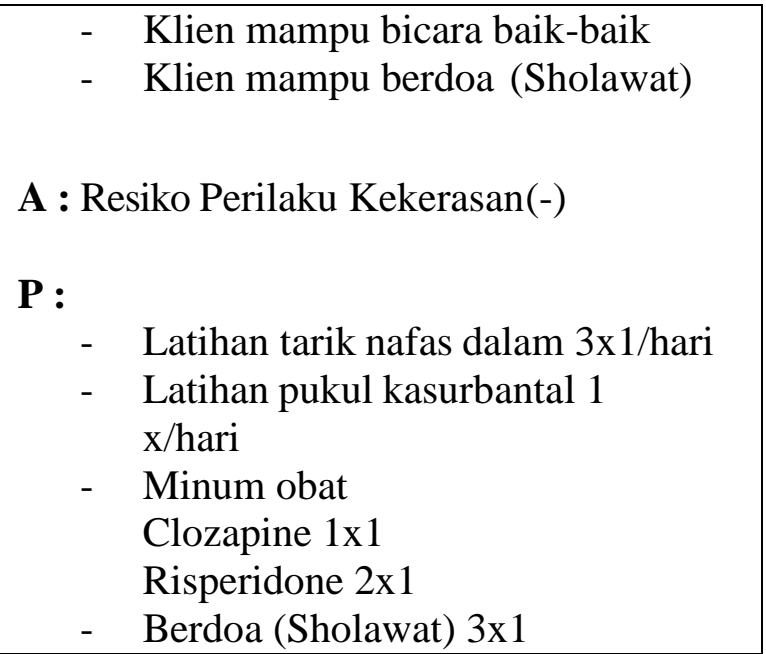 \\
\hline $\begin{array}{l}\text { Rabu, } 09 \\
\text { februri } 2022\end{array}$ & $\begin{array}{l}\text { 1. Data } \\
\text { Tanda dan gejala : Klien tampak malu, gelisah dan } \\
\text { bingung, dan tampak sedih saat di tanya perasaannya } \\
\text { 2. Diagnosa keperawatan : } \\
\text { Harga diri rendah kronik } \\
\text { 3. Tindakan keperawatan } \\
\text { Sp } 1 \text { HDRK } \\
\text { 1. Mengidentifikasi kemampuan dan aspek positif yang } \\
\text { dimiliki } \\
\text { 4. RTL: } \\
\text { Sp } 2 \text { HDRK } \\
\text { 1. Menilai kemamampuan yang dapat di gunakan } \\
\text { 2. Menetapkan/memilih kegiatan sesuai kemampuan } \\
\text { 3. Melatih kegiatan sesuai kemampuan yang dipilih } 1\end{array}$ & $\begin{array}{l}\text { S: } \\
\text { Klien mengatakan masih gelisah dan malu } \\
\text { O: } \\
\text {-Klien mampu memilih kemampuan yang } \\
\text { dimiliki(Membersihkan tempat tidur, } \\
\text { mencuci piring, bermain musik(gitar)) } \\
\text { A: } \\
\text { HDRK (+) } \\
\text { P: } \\
\text {-Membersihkan tempat tidur }\end{array}$ \\
\hline
\end{tabular}




\begin{tabular}{|c|c|c|}
\hline $\begin{array}{l}\text { Kamis, } 10 \\
\text { februari } 2022\end{array}$ & $\begin{array}{l}\text { 1. Data } \\
\text { Tanda dan gejala : Klien tampak malu, gelisah dan } \\
\text { bingung, dan tampak sedih saat di tanya perasaannya } \\
\text { 2. Diagnosa keperawatan : } \\
\text { Harga diri rendah kronik } \\
\text { 3. Tindakan keperawatan } \\
\text { Sp } 2 \text { HDRK } \\
\text { 1. Menilai kemamampuan yang dapat di gunakan } \\
\text { 2. Menetapkan/memilih kegiatan sesuai kemampuan } \\
\text { (Membersihkan tempat tidur) } \\
\text { 3. Melatih kegiatan sesuai kemampuan yang dipilih } 1 \\
\text { (Membersihkan tempat tidur) } \\
\text { 4. RTL: } \\
\text { Sp } 2 \text { HDRK } \\
\text { 1. Melatih kegiatan sesuai kemampuan yang dipilih } 2\end{array}$ & $\begin{array}{l}\text { S : } \\
\text { Klien mengatakan masih gelisah } \\
\text { O: } \\
\text {-Klien mampu Membersihkan tempat tidur } \\
\text { A: } \\
\text { HDRK (+) } \\
\text { P: } \\
\text {-Membersihkan tempat tidur }\end{array}$ \\
\hline $\begin{array}{l}\text { Senin, } 14 \\
\text { februari } 2022\end{array}$ & $\begin{array}{l}\text { 1. Data } \\
\text { Tanda dan gejala : Klien tampak malu dan gelisah, } \\
\text { dan tanpak sedih saat di kaji serta menundukkan } \\
\text { kepala } \\
\text { 2. Diagnosa keperawatan : }\end{array}$ & $\begin{array}{l}\text { S: } \\
\text { Klien mengatakan senang } \\
\text { O: } \\
\text {-Klien mampu mencuci piring }\end{array}$ \\
\hline
\end{tabular}




\begin{tabular}{|c|c|c|}
\hline & $\begin{array}{l}\text { Harga diri rendah kronik } \\
\text { 3. Tindakan keperawatan } \\
\text { Sp } 3 \text { HDRK } \\
\text { 1. Melatih kegiatan sesuai kemampuan yang dipilih } 2 \\
\text { (mencuci piring) } \\
\text { 4. RTL: } \\
\text { Sp } 4 \text { HDRK } \\
\text { 1. Melatih kegiatan sesuai kemampuan yang dipilih } 3\end{array}$ & $\begin{array}{l}\text { A: } \\
\text { HDRK }(+) \\
\text { P: } \\
\text {-Membersihkan tempat tidur } \\
\text {-Mencuci piring 1x1 hari }\end{array}$ \\
\hline $\begin{array}{l}\text { Selasa, } 15 \\
\text { februari } 2022\end{array}$ & $\begin{array}{l}\text { 1. Data } \\
\text { Tanda dan gejala : Klien tampak malu, gelisah dan } \\
\text { bingung, dan tampak sedih saat di tanya perasaannya } \\
\text { 2. Diagnosa keperawatan : } \\
\text { Harga diri rendah kronik } \\
\text { 3. Tindakan keperawatan } \\
\text { Sp } 4 \text { HDRK } \\
\text { 1. Melatih kegiatan sesuai kemampuan yang dipilih } 3 \\
\quad \text { (bermain gitar) } \\
\text { 4. RTL: } \\
\text { Evaluasi Sp1-Sp4 }\end{array}$ & $\begin{array}{l}\text { S : } \\
\text { Klien mengatakan senang } \\
\text { O: } \\
\text {-Klien mampu bermain gitar } \\
\text { A: } \\
\text { HDRK (-) } \\
\text { P: } \\
\text {-Membersihkan tempat tidur } \\
\text {-Mencuci piring } 1 \times 1 / \text { hari } \\
\text {-Bermain gitar } 2 \times 1 / \text { hari }\end{array}$ \\
\hline $\begin{array}{l}\text { Rabu, } 16 \\
\text { januari } 2022\end{array}$ & $\begin{array}{l}\text { 1. Data } \\
\text { Tanda dan gejala : Klien tampak malu dan gelisah, } \\
\text { dan tanpak sedih saat di kaji serta menundukkan } \\
\text { kepala }\end{array}$ & $\begin{array}{l}\text { S : } \\
\text { Klien mengatakan senang } \\
\text { O: }\end{array}$ \\
\hline
\end{tabular}




\begin{tabular}{|l|l|l|}
\hline $\begin{array}{l}\text { 2. } \text { Diagnosa keperawatan : } \\
\text { Harga diri rendah kronik } \\
\text { 3. Tindakan keperawatan } \\
\text { Evaluasi Sp1-Sp4 }\end{array}$ & $\begin{array}{l}\text {-Klien mampu membersihkan tempat tidur, } \\
\text { mencuci piring, bermain gitar }\end{array}$ \\
& A: \\
& HDRK (-) \\
& $\begin{array}{l}\text { P: } \\
\text {-Membersihkan tempat tidur } \\
\end{array}$ \\
\hline
\end{tabular}




\section{BAB 4 \\ PEMBAHASAN}

Setelah penulis melaksanakan asuhan keperawatan kepada Tn.L dengan gangguan sensori presepsi: halusianasi pendengaran di Ruang Sibual-buali maka penulis pada $\mathrm{BAB}$ ini akan membahas kesenjangan antara teoritis dengan tinjauan kasus. Pembahasan dimulai melalui tahapan proses keperawatan yaitu pengkajian, diagnosa keperawatan, perencanaan, pelaksanaan dan evaluasi.

\subsection{Pengkajian}

Pada laporan ini penulis melakukan pengkajian pada klien dengan gangguan persepsi sensori: Halusinasi Pendengaran pada skizofrenia paranoid. Pada Halusinasi Pendengaran di dapatkan klien Tn.L mengatakan, klien sulit tidur jika tidak dengan obat, gelisah, berbicara sendiri, klien mengatakan mendengar suara bisikan ibu mertuanya yang menuruhnya pergi.

Menurut yudi hartono \& farida kusumawati (2018) halusinasi merupakan hilangnya kemampuan manusia dalam membedakan rangsangan internal(pikiran) dan rangsang eksternal(dunia luar). Klien memberi persepsi atau pendapat tentang lingkungan tanpa objek atau rangsangan yang nyata. Sebagai contoh klien mengatakan mendengar suara padahal tidak ada orang yang berbicara. Gejala gangguan jiwa dimana klien mengalami perubahan persepsi sensori: merasakan sensori palsu berupa suara, penglihatan, pengecapan atau penghiduan

Menurut penulis, Halusinasi Pendengaran pada Tn.L adalah faktor psikologis dan sosiokultural. Keduanya berkaitan dimana hubungan interpersonal yang tidak harmonis antara klien dengan mantan istri dan ibu mertuanya, Klien pernah menikah 2 kali namun bercerai karena tidak mampu menafkahi istrinya dan ingin berencana untuk menikah lagi namun gagal lagi, klien merasa gagal untuk menjadi suami, putus asa dan mulai mendengar suara tanpa wujud yang 
menyuruhnya pergi. Masyarakat sekitar akhirnya resah dan ketakutan ketika klien berkeliaran di lingkungan masyarakat, sehingga masyarakat menjahui klien karena takut. Dan akhirnya klien menyendiri dan sering mengalami halusinasi.

Setelah kejadian perceraian Tn.L klien lebih sering marah, kesal, dan sulit mengontrol emosinya, Tn.L pernah memukul ibunya karena kesal ibunya selalu bertanya kepadanya. Klien juga mengatakan sering melempar barangbarang. Pada saat dinas di ruang Pusuk Buhit penulis melihat Tn.L memukul teman nya karena tidak mau mendengarkan perkataannya. Saat di Tanya Tn.L sulit mengontrol emosinya. Namun saat penulis bertanya mengenai perasaannya Tn.L menjadi sedih dan menundukan kepala, Tn.L menyesal dengan yang di lakukan nya, dan klien mengatakan sebenarnya klien malu dengan penyakitnya ini, merasa tidak berguna karena masa lalu nya, trauma ingin menikah lagi. Takut tidak mampu menafkahi istrinya lagi. Klien juga tidak mau pulang karena takut di kucilkan. Hal ini menyebabkan klien menjadi sering termenung memikirkan hal-hal tersebut dan muncul kembali suara-suara tersebut yang mengganggu nya.

\subsection{Diagnosa Keperawatan}

Dari data yang di temukan muncul masalah keperawatan Seperti : Gangguan persepsi sensori: Halusinasi Pendengaran, Prilaku kekerasan, Harga diri rendah kronik.

\subsection{Intervensi Keperawatan}

Perencanaan yang diberikan pada klien gangguan persepsi sensori: halusinasi pendengaran adalah BHSP: membina hubungan saling percaya dengan klien dan memberi salam terapiutik dengan memanggil nama klien, menyebutkan nama perawat, jelaskan tujuan interaksi, ciptakan lingkungan yang tenang, buat kontrak yang jelas(topik yang dibicarakan, waktu dan tempat), yakinkan bahwa kerahasiaan klien senantiasa terjaga, tanyakan harapan terhadap pertemuan, dorong dan beri kesempatan untuk klien mengungkapkan 
perasaannya, dengarkan ungkapan klien dengan empati, lakukan pengkajian data (sesuai format askep pengkajian). Klien mampu mengenali halusinasi yang dialaminya, dan mengikuti program pengobatan secara optimal meliputi mengidentifikasi jenis, isi dan frekuensi halusinasi klien, identifikasi situasi yang menimbulkan halusinasi, identifikasi respon klien terhadap halusinasi, bimbing klien memasukkan dalam jadwal harian. Klien mampu mengontrol halusinasinya meliputi evaluasi masalah dan latihan sebelumnya, latih klien cara mengontrol halusinasi dengan menghardik, latih cara mengontrol halusinasi dengan cara berbincang dengan orang lain, latih klien cara mengontrol halusinasi dengan kegiatan(yang bisa dilakukan klien), menjelaskan cara mengontrol halusinasi dengan teratur minum obat(prinsip 6 benar minum obat), masukkan dalam jadwal kegiatan klien.

Pada tahap perencanaan penulis menyusun rencana tindakan keperawatan sesuai dengan pohon masalah keperawatan yaitu : Halusinasi pendengaran. Pada tahap ini antara tinjauan teoritis dan tinjaun kasus tidak ada kesenjangan sehingga penulis dapat melaksanakan tindakan seoptimal mungkin dan didukung dengan seringnya bimbingan dengan pembimbing. Secara teoritis digunakan cara strategi pertemuan sesuai dengan diagnosa keperawatan yang muncul saat pengkajian. Adapun upaya yang dilakukan penulis yaitu :

Halusinasi pendengaran

Mengidentifikasi isi Halusinasi

$>$ Mengidentifikasi waktu terjadi Halusinasi

$>$ Mengidentifikasi situasi pencetus Halusinasi

$>$ Mengidentifikasi perasaan terhahap Halusinasi

$>$ Mengidentifikasi respon terhadap Halusinasi

$>$ Membantu klien mempraktekan latihan cara mengontrol Halusinasi dengan menghardik

$>$ Menjelaskan cara mengontrol Halusinasi dengan minumobat

$>$ Melatih bercakap-cakap dengan orang lain

> Melatih melakukan kegiatan terjadwal klien 
Perilaku Kekerasan

Mengidentifikasi isi Perilaku Kekerasan

Mengidentifikasi waktu terjadi Perilaku Kekerasan

$>$ Mengidentifikasi situasi pencetus Perilaku Kekerasan

> Mengidentifikasi respon terhadap Perilaku Kekerasan

> Membantu klien mempraktekan latihan cara mengontrol Perilaku Kekerasan dengan tarik napas dalam dan pukul kasur bantal

$>$ Menjelaskan cara mengontrol perilaku kekerasan dengan minumobat

$>$ Melatih klien mengontrol Perilaku Kekerasan denganberbicara baikbaik dengan orang lain dan spritual

$>$ Mengevaluasi jadwal kegiatan harian klien

\section{Harga Diri Rendah Kronik}

> Mengidentifikasi kemampuan dan aspek positif yang dimiliki klien

$>$ Membantu klien menilai kegiatan sesuai kemampuan

$>$ Membantu klien menetapkan kegiatan sesuai kemampuan

> Membantu klien melatih kegiatan sesuai kemempuan yang dipilih 1

$>$ Membantu klien melatih kegiatan sesuai kemempuan yang dipilih 2

> Membantu klien melatih kegiatan sesuai kemempuan yang dipilih 3

\subsection{Tahap Implementasi}

Pada tahap implementasi, penulis mengatasi 3 masalah keperawatan yakni: diagnosa keperawatan Halusinasi pendengaran, Perilaku Kekerasan, HDRK. Pada diagnosa keperawatan Halusinasi pendengaran di lakukan strategi pertemuan yang pertama mengidentifikasi isi, frekuensi, waktu terjadi, situasi pencetus, perasaan, dan respon halusinasi, mengajarkan klien mengontrol halusinasi dengan menghardik, memasukkan cara menghardik ke dalam jadwa.l Strategi pertemuan kedua yaitu dengan mengajarkan klien mengontrol halusinasi dengan minum obat secara teratur (Risperidone $2 \times 1$, Clozapine 1x1) dan memasukan minum obat teratur ke jadwal. Pertemuan ketiga evaluasi pertemuan 1 dan 2 kemudian mengajarkan klien mengontrol halusinasi dengan bercakap-cakap dengan orang lain ketika halusinasi 
muncul, Strategi keempat mengajarkan klien mengontrol halusinasi dengan melakukan kegiatan terjadwal, Kemudian di lakukan evaluasi dari pertemuan pertama sampai pertemuan keempat, memantau perkembangan klien klien sampai masalah teratasi.

Pada masalah keperawatan Perilaku Kekerasan dilakukan strategi pertemuan yaitu mengidentifikasi Perilaku Kekerasan, mengontrol perilaku kekerasan dengan cara tarik napas dan pukul kasur bantal dan memasukan ke jadwal. Strategi pertemuan yang kedua yaitu anjurkan minum obar secara teratur (Risperidone $2 \times 1$, Clozapine $1 \times 1$ ), strategi pertemuan ketiga yaitu latihan dengan cara komunikasi secara verbal atau bicara baik-baik strategi pertemuan ke empat yaitu Spritual melatih klien bersholawat. Kemudian di lakukan evaluasi dari pertemuan pertama sampai pertemuan keempat, memantau perkembangan klien klien sampai masalah teratasi

Menurut penulis tidak menemukan hambatan secara keseluruhan dalam melakukan tindakan yang dimulai dari SP 1 sampai SP 4 karena klien kooperatif, mampu mengingat dan mempraktikkan dengan baik.

\subsection{Tahap evaluasi}

1. Halusinasi Pendengaran

Pada tinjauan teoritis evaluasi yang diharapkan adalah:

Klien mempercayai perawat sebagai terapis

$>$ Dapat mengidentifikasi isi, waktu terjadi, situasi pencetus, perasaan, dan respon Halusinasi

Dapat mengontrol Halusinasi dengan cara menghardik

D Dapat mengontrol Halusinasi dengan cara minumobat teratur

$>$ Dapat mengontrol Halusinasi dengan cara bercakap-cakap dengan orang lain

$>$ Dapat mengontrol Halusinasi dengan cara melakukan kegiatan terjadwal klien

Pada tinjauan kasus evaluasi yang dihasilkan adalah : 
$>$ Klien sudah Dapat mengidentifikasi isi, waktu terjadi, situasi pencetus, perasaan, dan respon Halusinasi

Klien Dapat mengontrol Halusinasi dengan cara menghardik

$>$ Klien Dapat mengontrol Halusinasi dengan cara minumobat teratur

$>$ Klien Dapat mengontrol Halusinasi dengan cara bercakap-cakap dengan orang lain

Klien Dapat mengontrol Halusinasi dengan cara melakukan kegiatan terjadwal klien 


\section{BAB 5}

\section{PENUTUP}

\subsection{Kesimpulan}

1. Hasil pengkajian yang diperoleh adalah data subjektif dan objektif pada kasus Tn.L dan didapatkan data : Klien sebelumnya pernah di rawat di rsj 1 tahun yang lalu, kembali lagi karena tidak rutin kontrol dan tidak patuh minum obat, Klien meresahkan warga sekitar. Klien pernah menikah 2 kali namun bercerai karena Tn.L tidak mampu menafkahi istrinya Dan ingin menikah lagi tetapi gagal. Klien mendengar suara-suara tanpa wujud, suara tersebut adalah suara ibu mertuanya yang menyuruhnya pergi. Klien merasa kesal karena suara tersebut selalu datang dan tekadang tidak mampu menahan amarahnya.

2. Diagnosa Keperawatan yang ditemukan oleh penulis pada saat pengkajian adalah Gangguan Persepsi Sensori : Halusinasi Pendengaran, Resiko Perilaku Kekerasan, Harga Diri Rendah berdasarkan analisa data yaitu dari data subjektif dan objektif.

3. Rencana keperawatan yang dilakukan adalah dengan tujuan klien dapat mengenal halusinasinya, dapat mengontrol Resiko perilaku Kekerasan dan Harga Diri Rendah, dengan cara mendiskusikan dengan klien tentang penyakit yang dialaminya 
4. Implementasi keperawatan yang dilakukan penulis selama 6 hari yaitu membantu klien mengenal halusinasinya, mengontrol resiko perilaku kekerasan, dan harga diri rendah. mengidentifikasi penyebab, isi, jenis, waktu,setra tanda dan gejala dari penyakitnya.

5. Evaluasi yang dilakukan penulis sesuai dengan diagnosa keperawatan yang ada pada Tn.L yaitu gangguan persepsi sensori: halusinasi pendengaran resiko perilaku kekerasan, dan harga diri rendah. sesuai dengan implementasi dan bagaimana perkembangan klien. Klien mampu melakukan strategi pelaksanaan (SP) dari sp 1-sp 4 dengan baik dan menunjukkan perubahan klien lebih tampak rileks, tidak mendengar suara lagi, dan dapat meminum obat secara teratur, dan klien dapat mempraktekkan cara mengontrolnya menggunakan sp yang sudah dipelajari tetapi klien.

\subsection{Saran}

1. Bagi pasien dan keluarga

Keluarga dapat ikut serta dalam memberikan asuhan keperawatan pada klien gangguan persepsi sensori : halusinasi pendengaran, sehingga klien merasa ada dukungan yang dapat mempercepat proses penyembuhan penyakitnya.

\section{Bagi Perawat}

Diharapkan dapat menerapkan komunikasi terapeutik dalam pelaksanaan strategi pertemuan 1-4 pada klien dengan halusinasi pendengaran sehingga dapat mempercepat proses pemulihan klien. 
3. Bagi Institusi Pendidikan

Dapat meningkatkan bimbingan klinik kepada mahasiswa profesi ners sehingga mahasiswa semakin mampu dalam melakukan asuhan keperawatan pada pasien-pasien dengan Halusinasi pendengaran.

4. Bagi Rumah Sakit

Laporan ini diharapkan dapat menjadai acuan dan referensi dalam memberikan asuhan keperawatan pada klien dengan halusinasi pendengaran 


\section{Daftar Pustaka}

1. Dalami E, dkk. (2015). Asuhan Keperawatan Pasien Dengan Gangguan Jiwa. Jakarta: CV. Trans Info Media.

2. Davison. dkk (2015). Psikologi Abnormal. Edisi ke 9. Jakarta : PT. Raja Grafindo Perdasa

3. Pardede, J. A., Keliat, B. A., \& Yulia, I. (2015). Kepatuhan dan Komitmen Klien Skizofrenia Meningkat Setelah Diberikan Acceptance And Commitment Therapy dan Pendidikan Kesehatan Kepatuhan Minum Obat. Jurnal Keperawatan Indonesia, 18(3), 157-166. https://doi.org/10.7454/jki.v18i3.419

4. Ervina,I., \& Hargiana, G. (2018). Aplikasi keperawatan Generalis dan Psikoreligius pada pasien pada gangguan sensori persepsi: Halusinasi penglihatan dan pendengaran. Jurnal Riset Kesehatan Nasional, 2(2), 114-123. http://dx.doi.org/10.37294/jrkn.v2i2.106

5. Halawa, A. (2017). Pengaruh Terapi Aktivitas Kelompok: Stimulasi Persepsi Sesi 1-2 Terhadap Kemampuan Mengontrol Halusinasi Pendengaran Pada Pasienskizofrenia Di Ruang Flamboyan Rumah Sakit Jiwamenur Surabaya. Jurnal Keperawatan, 4(1), 30-37.

6. Keliat B, dkk. (2017). Proses Keperawatan Jiwa Edisi II. Jakarta : EGC.

7. Kemenkes RI. (2019).Riset Kesehatan Dasar, RISKESDAS.Jakarta: Kemenkes RI.

8. https://databoks.katadata.co.id/datapublish/2019/10/08/persebar an-prevalensi-skizofreniapsikosis-di-indonesia\#

9. Kusmiawati, Farida \& Yudi H. (2015). Buku Ajar Keperawatan Jiwa. Jakarta : Salemba Medika

10. Manao, B. M., \& Pardede, J. A. (2019). Correlation of Family Burden of The Prevention of Recurrence of Schizophrenia Patients. Mental Health, 4(1), 3142.

11. Pardede, J. A. (2021). Standar Asuhan Keperawatan Dengan Kesiapan Peningkatan Pengetahuan.

12. Muhith, A. (2015). Pendidikan Keperawatan Jiwa. Jakarta: Penerbit ANDI.

13. Oktiviani, D. P. (2020). Asuhan Keperawatan Jiwa Pada Tn. K dengan masalah Gangguan Persepsi Sensori: Halusinasi Pendengaran di Ruang Rokan Rumah Sakit Jiwa Tampan. Skripsi, Poltekkes Kemenkes Riau. http://repository.pkr.ac.id/id/eprint/498

14. Riskesdas. (2018). Badan Penelitian dan Pengembangan Kesehatan. Jakarta: Dapertemen Kesehatan Republik Indonesia.

15. Pardede, J. (2020). Family Knowledge about Hallucination Related to Drinking Medication Adherence on Schizophrenia Patient. Jurnal Penelitian Perawat Profesional, 2(4), 399-408. https://doi.org/10.37287/jppp.v2i4.183

16. Pardede, J. A., \& Hasibuan, E. K. (2020). Lamanya Perawatan Pasien Skizofrenia Rawat Jalan Dengan Tingkat Stres Keluarga. Indonesian Trust Health Journal, 3(1), 283-288. https://doi.org/10.37104/ithj.v3i1.49 
17. Pardede, J. A., Silitonga, E., \& Laia, G. E. H. (2020). The Effects of Cognitive Therapy on Changes in Symptoms of Hallucinations in Schizophrenic Patients. Indian Journal of Public Health Research \& Development, 11(10).

18. Pardede, J. A. (2020). Family Burden Related to Coping when Treating Hallucination Patients. Jurnal Ilmu Keperawatan Jiwa, 3(4), 453-460. https://doi.org/10.32584/jikj.v3i4.671

19. Pardede, J.A.,\& Siregar, R.A. (2016). Pendidikan Kesehatan Keptauhan Minum Obat Terhadap Perubahan Gejala Halusinasi Pada pasien skizofrenia. Mental Health, 3(1)

20. Pitayanti, A., \& Hartono, A. (2020). Sosialisasi Penyakit Skizofrenia Dalam Rangka Mengurangi Stigma Negatif Warga di Desa Tambakmas KebonsariMadiun. Journal of Community Engagement in Health, 3(2), 300-303. https://jceh.org/index.php/JCEH/article/view/83/78

21. Pardede, J. A., Siringo-ringo, L. M., Hulu, T. J., \& Miranda, A. (2021). Edukasi Kepatuhan Minum Obat Untuk Mencegah Kekambuhan Orang Dengan Skizofrenia. Jurnal Abdimas Mutiara, 2(2), 1-5.

22. Yudi Hartono Dan Farida Kusumawati, Buku Ajar Kperawatan Jiwa, Jakarta: Salemba Medika, 2010

23. Pardede, J. A., Irwan, F., Hulu, E. P., Manalu, L. W., Sitanggang, R., \& Waruwu, J. F. AP (2021). Asuhan keperawatan Jiwa Dengan Masalah Halusinasi, 10.

24. Pardede, J. A. (2020). Beban Keluarga Berhubungan Dengan Koping Saat Merawat Pasien Halusinasi. Jurnal Ilmu Keperawatan Jiwa, 3(4), 445-452. 